\title{
THE ROLE OF RIVER CHANNEL ROUGHNESS FOR WATER LEVEL MODELING DURING THE 2005 YEAR FLOOD ON SIRET RIVER USING HEC-RAS MODEL
}

\author{
Maxim Arseni ${ }^{*}, 1$, Adrian Rosu ${ }^{1}$, Gabriel Murariu ${ }^{1}$, Lucian Puiu Georgescu ${ }^{1}$, \\ Catalina Iticescu ${ }^{1}$, Calmuc Madalina $^{1}$, Calmuc Valentina ${ }^{1}$ \\ ${ }^{1}$ Faculty of Science and Environment, European Center of Excellence for the Environment, "Dunarea de Jos" \\ University of Galati, 111, Domneasca Street, RO-800201, Galati, Romania \\ *Corresponding author: maxim.arseni@ugal.ro
}

\begin{abstract}
At present, the value of channel roughness represents the most important parameter of hydraulic model calibration for flood mapping and flood forecasting. In practice, the roughness coefficient (Manning's " $n$ " value) cannot be determined from in situ surveying, but it can be automatically extracted from alternative sources, like pedological maps, ortophotomaps by digitizing each polygon associated with "n" value or using satellite images LANDSAT. For calibration of Manning's "n" values, it was used the data from 2005, when a major flood occurred in this study area. To verify the performance of the calibrated HEC-RAS model, it was analyzed the flood peaks of observed and simulated values, and computation of root mean square error for the used hydrograph station on the lower Siret River. The study aims to present an efficient calibration method for flood mapping using HEC-RAS model.
\end{abstract}

Keywords: roughness coefficient, Manning's value, HEC-RAS, flood, Siret River

\section{INTRODUCTION}

Floods are very devastating natural disasters and can bring many losses of human lives, material, infrastructure or economic damages [1]. This type of natural phenomenon is also increasing due to the anthropic factor. Floods are increasing globally and due to global climate change. It is, therefore, necessary to establish effective measures, plans, and strategies for the determination and management of flood risks [2]. According to Directive 2007/60 / EC of the European Parliament on "The assessment and management of flood risks" [3] an important goal is the prediction with uncertainty as small as possible of the flood risk reduction and immediate response to negative effects. The viability of river systems and their health depend directly on certain features of the open channels, such as flow regime, flow rate, geometric characteristics of the minor and major riverbed, natural or artificial dams or the type of land surface in the study area.

In view of the above, a great importance for the assessment of the minimum flow regime is the determination of the type of land cover surface, this in turn directly influencing the determination of Manning coefficients of roughness for each cross-section part in the minor riverbed and major riverbed [4]. Numerous series of tables with roughness coefficients have been developed in the scientific literature so that the contribution to bed friction can be calculated exactly when simulated hydrodynamics are made for the determination of discharge and water level [5]. Chezy was the first scholar who considered that the wet perimeter of the cross section is a friction at the limit in the flow 
channel. Chezy was the first researcher who considered that the wet perimeter of the cross-section has a limit of friction in the flow channel. Thus, the formula proposed by Chezy and described by Te Chow, 1953 [6] is used to compute the average section velocity. Selecting an appropriate value for the Manning's roughness coefficient is the most important parameter for estimating the flow rate in open chanels. Acrement and Schneider [7], and Nayak [8] considered that the variance of the roughness coefficient for direct channel coverage due to slope, geometry and flow depth is not significant compared to that for meandered channels.

Considering this point of view, the primary purpose of this study was to define the relation between basic values of the Manning roughness coefficient „n” and the calibration of flood peak values. By analyzing the scientific literature, there are numerous investigations about the resistance to flow in open channels, but which do not provide a complete understanding of the method of determining the roughness coefficient.

\section{STUDY AREA}

The study area is a $35 \mathrm{~km}$ river reach along the lower Siret River, section Galati-SendreniIndependenta. The study reach is located downstream from the confluence with Danube River, and 35 $\mathrm{km}$ upstream, up to Independenta village and forms the border between Galati and Braila Counties. The Siret riverbed material is composed of a combination of fine sand and silt. To analyze the influence of channel roughness coefficients on the calibration of the HEC-RAS model, the study area was defined by cross-section along the measured river section (Appendix 1). The cross sections were defined at approximately equal distances along the course of the river, and in areas where there are bridges, accentuated declivities, pronounced roughness changes, or in areas where the meanders are very sinusoidal, the cross sections were geometrically spaced at as small distances possible, so as to describe as accurately as possible the geometry of the main channel.

Over time, the Siret River and its tributaries have produced considerable floods such as those from 1969 to 2016 (Fig. 1) which caused a series of damages (Fig. 2).

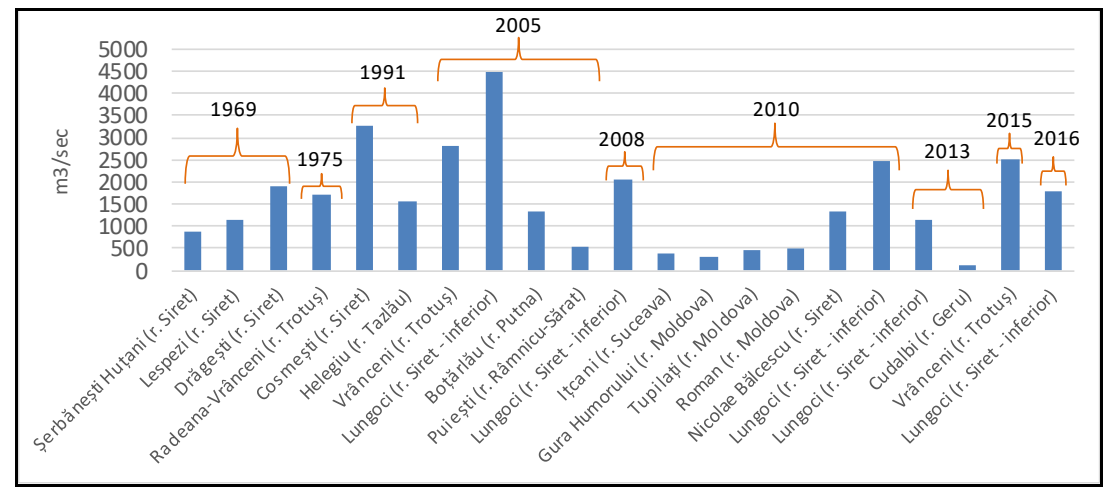

Fig. 1. Maximum historical flows recorded on Siret River and its tributaries [9], [10]

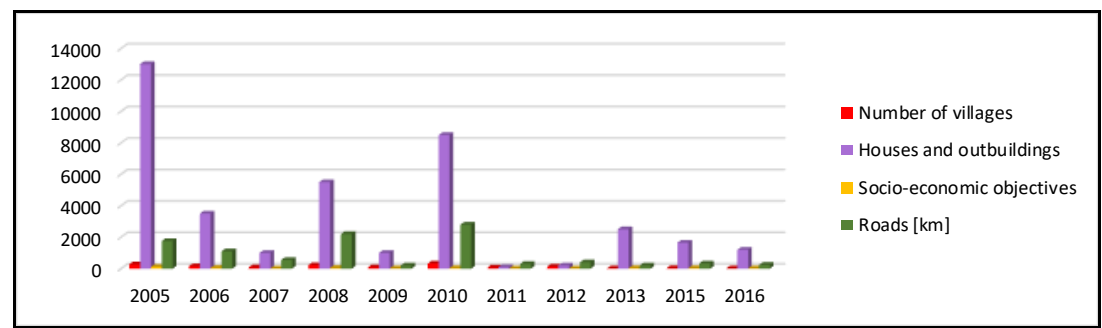

Fig. 2. Damage caused by historical floods from 2005 to 2016 [9], [10]

\section{MATERIALS AND METHODS}

Terrain roughness values are one of the important aspects of any hydraulic modeling. In fact, the roughness is almost impossible to determine by in situ measurements, so roughness is usually 
estimated from alternative sources, such as pedological maps, orthophotoplans or LANDSAT satellite imagery [11]. To achieve satisfactory results, in the literature are described and modeled, different combinations of roughness values [1], [7], [12]. In this research paper, based on the physical characteristics of the minor and major riverbeds, 8 classes of roughness presented in Table 1 were used.

Table 1. The " $n$ " coefficients of roughness [6]

\begin{tabular}{|c|c|c|c|c|}
\hline Category & Description & Minimum & Normal & Maximum \\
\hline \multicolumn{5}{|c|}{ 1. Minor riverbed } \\
\hline & a. Sand-clay, multiple meanders, banks, rare stones & 0.030 & 0.050 & 0.070 \\
\hline \multicolumn{5}{|c|}{ 2. Major riverbed } \\
\hline & a. Grass land & 0.030 & 0.035 & 0.050 \\
\hline & b. Short grass & 0.035 & 0.040 & 0.045 \\
\hline & c. Arable land & 0.033 & 0.045 & 0.055 \\
\hline & d. Brushwood & 0.070 & 0.110 & 0.160 \\
\hline & e. Thick trees, knobs, broken branches & 0.080 & 0.120 & 0.140 \\
\hline & $\begin{array}{l}\text { f. Broadleaf trees, willows, thick leaves during the } \\
\text { summer }\end{array}$ & 0.110 & 0.150 & 0.200 \\
\hline \multicolumn{5}{|c|}{ 3. Urban area } \\
\hline & a. Asphalt, pavement & 0.012 & 0.015 & 0.020 \\
\hline
\end{tabular}

Usually, the flow rate in the minor bed is not divided into smaller sections within a crosssection, with the mention that the Manning roughness coefficients do not change, otherwise, the minor bed is divided into the smaller subdivisions section. Experiments given by HEC-RAS experts have tested the applicability of subdivisions in the minor bed. Thus, the program determines whether it is necessary to subdivide the cross section into the minor bed using the following criteria: if the slope of the minor bed is higher than $5 \mathrm{H}: 1 \mathrm{~V}$ and the minor bed has more Manning roughness coefficients defined, then the minor bed will be subdivided into more small sections each of these with individual roughness coefficients. The side slope of the minor riverbed used in HEC-RAS is determined by the ratio between the horizontal distance between two roughness coefficients defining a subdivision and the difference of elevation two characteristic points $\left(\mathrm{P}_{\mathrm{d}}\right.$ and $\mathrm{P}_{\mathrm{s}}$ in Fig. 3).

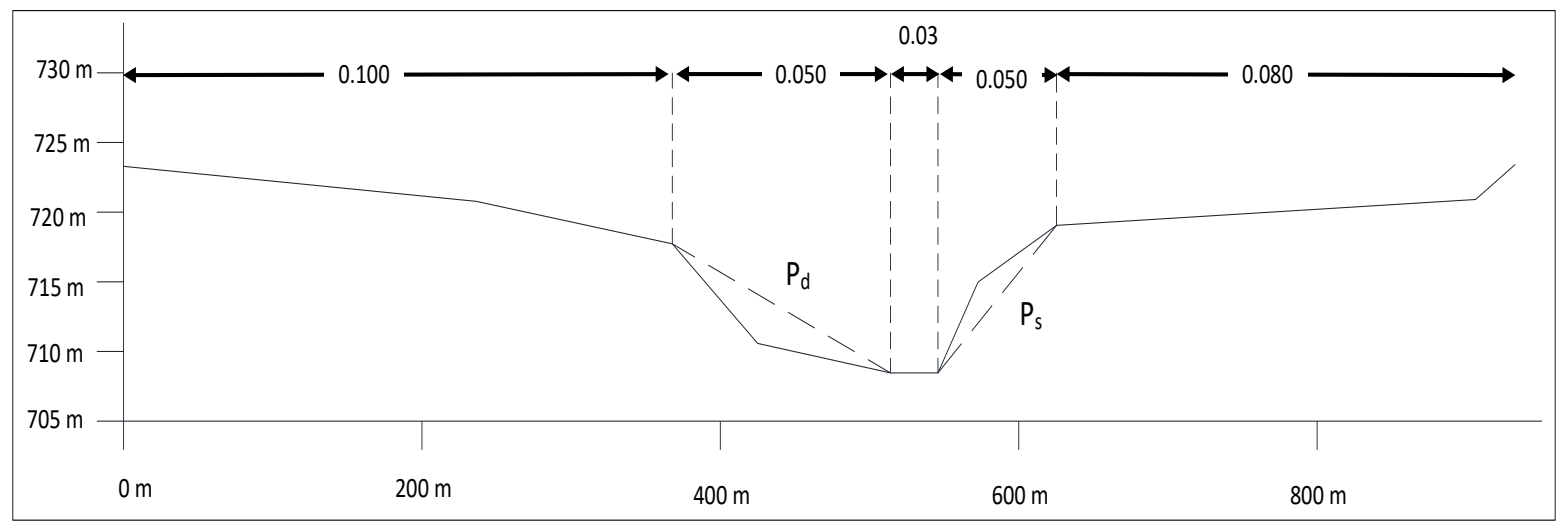

Fig. 3. Definition of bank slope for composite $n_{c}$ calculation [13]

For the calculation of the $n_{c}$ coefficient, the minor bed is divided into $N$ parts, each subdivision having the known wet perimeter $\left(P_{i}\right)$ and the coefficient of roughness $n_{i}$ (Eq. (1)).

$$
n_{c}=\left[\frac{\sum_{i=1}^{N}\left(P_{i} n_{i}^{1.5}\right)}{P}\right]^{2 / 3}
$$


where: $n_{c}=$ composite or equivalent coefficient of roughness; $P=$ wetted perimeter of the entire main channel; $P_{i}=$ wetted perimeter of subdivision $I ; n_{i}=$ coefficient of roughness for subdivision.

\section{RESULTS AND DISCUSSION}

In this research paper, the Manning's values for the minor riverbed ranges between 0.030 and 0.070 depending on the natural features of the river. The roughness coefficients have been adapted so as to ensure a numerical correspondence between the values measured at the hydrographic stage and the modeled values. The polygons that determine each area with the value of the roughness coefficients were digitized on the basis of the $0.5 \mathrm{~m}$ precision orthophotomap (Fig. 4), according to eight different roughness classes described in Table 1. The result of polygon limits for the determination of roughness coefficients is highlighted by a color ramp and represented in Figure 5 . The roughness coefficients distribution is presented in raster format in Figure 6.

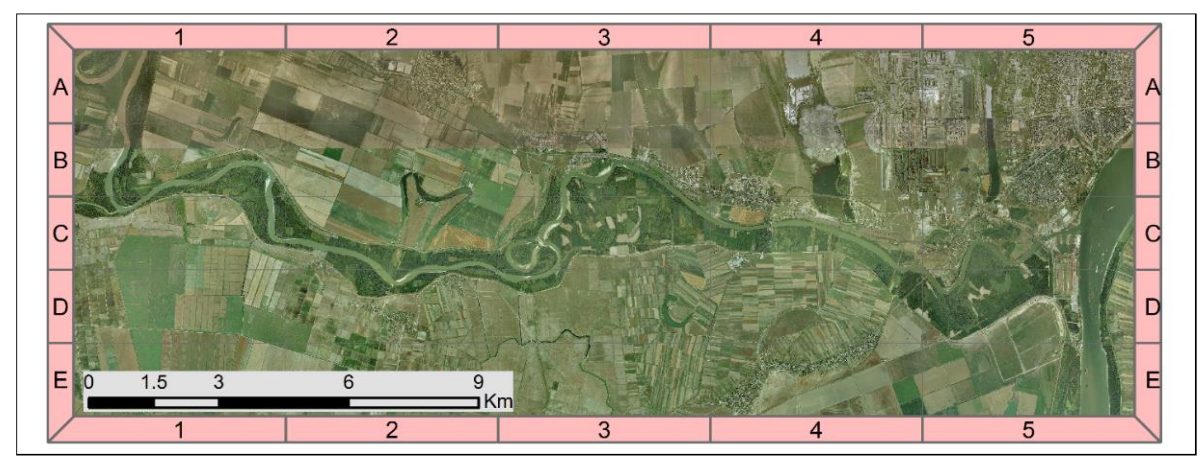

Fig. 4. Orthophotomap with 0.5 m precision of Galați-Brăila City

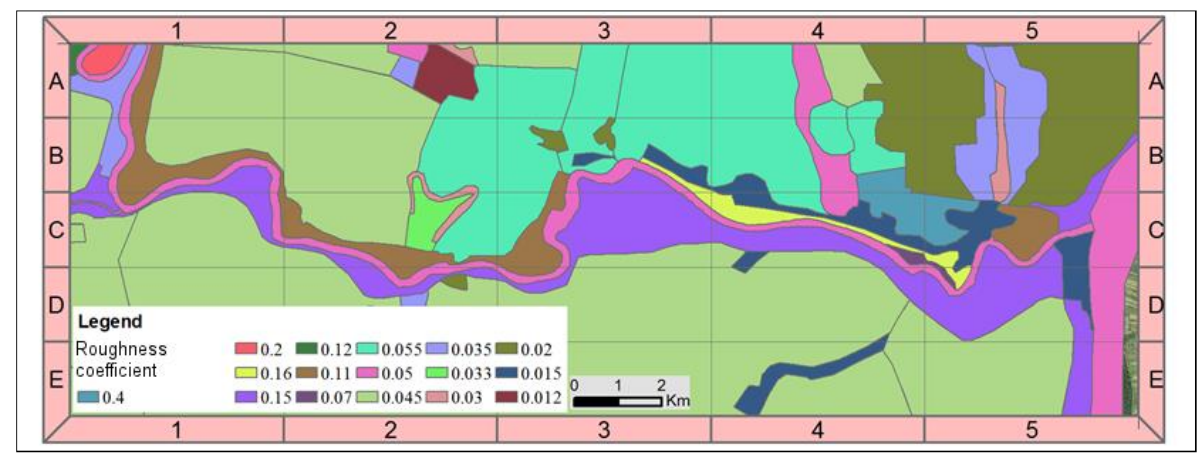

Fig. 5. The roughness coefficients assigned by digitized polygons

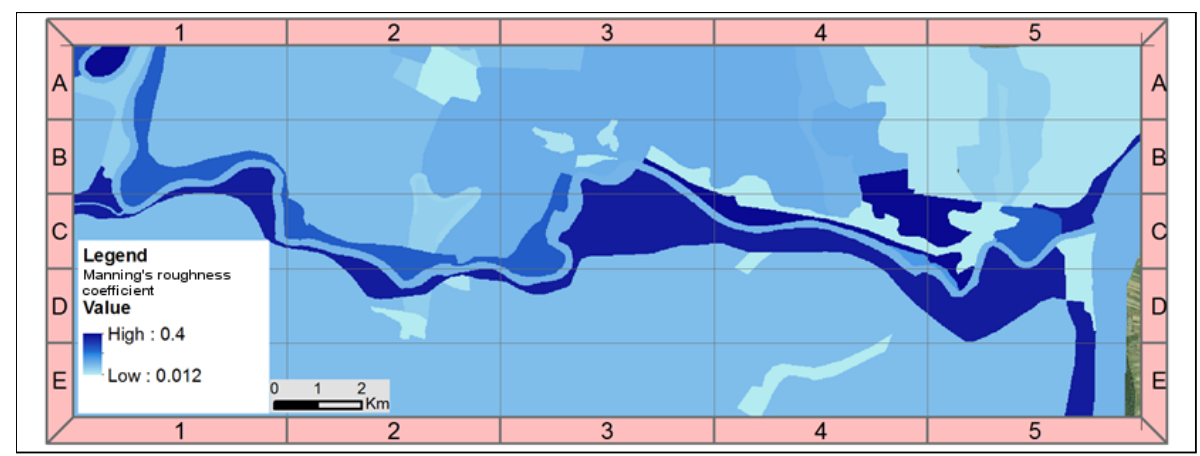

Fig. 6. The rasterized map of roughness coefficient distributions

The roughness coefficients were extracted using an automated GIS method. The cross-sections were superimposed over the raster pattern and so each subdivision of the cross-sectional profile 
obtained the values of the polygons with the different land cover surface. Figure 7 and 8 shows the $\mathrm{km}$ $32+0.187$ cross sections (profile 1 from the upstream river of the study area) and $\mathrm{km} 8+0.937$ (cross-section profile upstream of the Şendreni bridge), characterized by the previously specified Manning roughness coefficients and extracted automatically on the rasterized map.

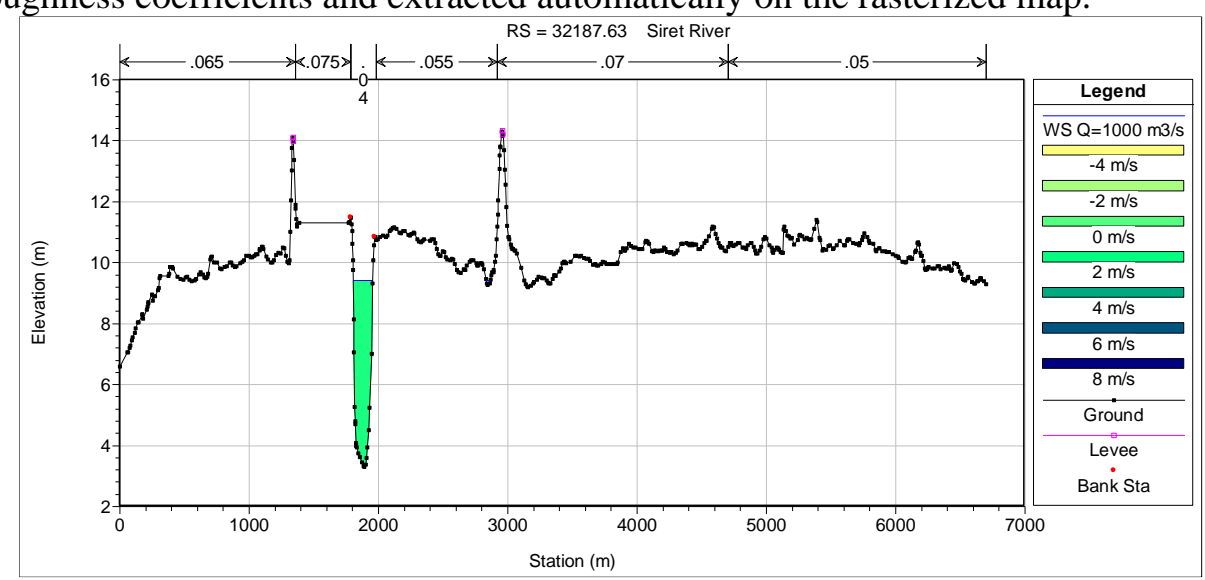

Fig. 7. Manning's roughness value for each subdivision of $\mathrm{km} 32+0.187$ cross-section

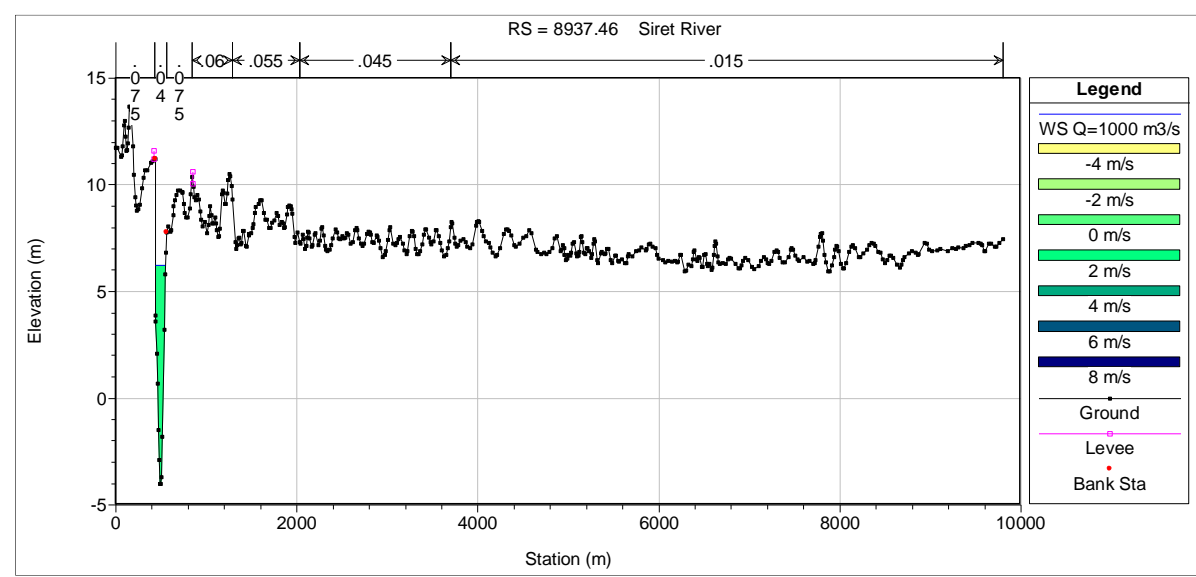

Fig. 8. Manning's roughness value for each subdivision of $\mathrm{km} 8+0.936$ cross-section

Due to the lack of a complex set of data on the studied area, for this research paper, the model analysis and calibration were limited to the comparison of surface water levels from modeling with surface levels found in the scientific literature and in the field. These are based on the major flood that occurred in 2005 [14]. The water surface level was registered at the Sendreni hydrometric station (Fig. 9) If we analyze the limnimetric key from Sendreni hydrometric station, it can be observed that are 3 critical moments, represented with red triangles, that describe the water level what can happen at 20, 50 and 100-year risk of flood. 


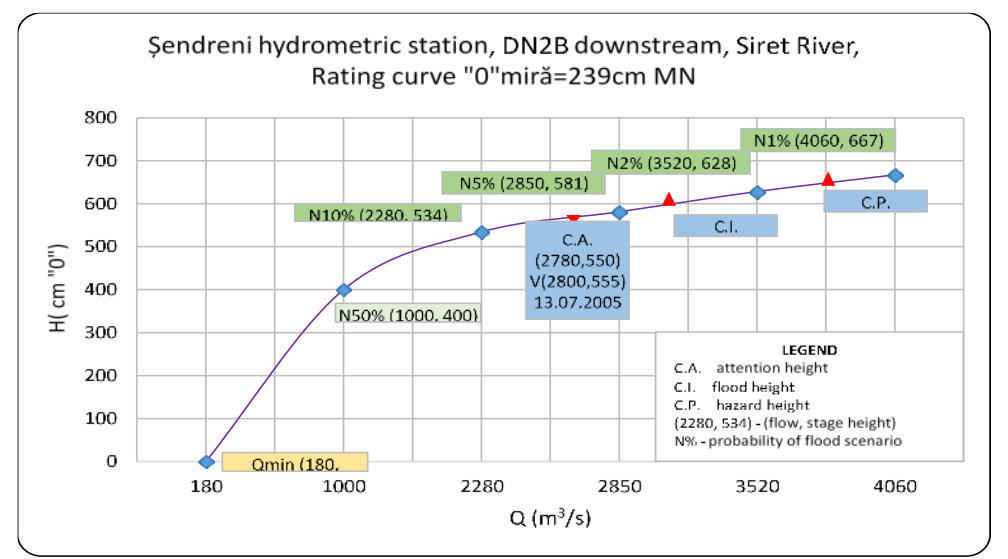

Fig. 9. Registered rating curve values at the Sendreni hydrometric station during the 2005 flood year

The calibration of the model was performed by roughness coefficients modification in the minor riverbed so that the differences between the measured rating curve key and the modeled rating curve key were less than $\pm 20 \mathrm{~cm}$ (Fig. 10).

Calibration of the model was achieved by modifying roughness values of the terrain, especially those that represent the minor riverbed. Table 2 presents the comparative results between the observed values and the modeled values at the Șendreni hydrographic stage. The comparative results between the measured and modeled limniteric key are also graphically represented in Figure $10 \mathrm{a}-\mathrm{f}$.

Table 2. The registered value of water surface elevation at different discharge testing

\begin{tabular}{|c|c|cccccc|}
\hline Discharge & Measured water & \multicolumn{7}{|c|}{ Modeled water level } \\
\cline { 3 - 7 }$\left(\mathrm{m}^{3} / \mathrm{s}\right)$ & level $(\mathrm{m})$ & $\mathrm{n}=0.07$ & $\mathrm{n}=0.06$ & $\mathrm{n}=0.05$ & $\mathrm{n}=0.04$ & $\mathrm{n}=0.03$ & $\mathrm{n}=0.02$ \\
\hline 180 & 2.39 & 4 & 3.7 & 3.36 & 2.29 & 2.29 & 1.76 \\
1000 & 6.39 & 9.14 & 8.79 & 8.13 & 6.26 & 5.41 & 3.97 \\
2280 & 7.73 & 10.98 & 10.59 & 9.93 & 7.62 & 8.33 & 6.38 \\
2780 & 7.89 & 11.74 & 11.26 & 10.43 & 8.14 & 9.16 & 7.17 \\
2800 & 7.94 & 11.75 & 11.29 & 10.44 & 8.19 & 9.18 & 7.2 \\
2850 & 8.25 & 11.78 & 11.36 & 10.5 & 8.22 & 9.24 & 7.28 \\
3100 & 8.39 & 10.22 & 11.69 & 10.79 & 8.52 & 9.49 & 7.64 \\
3520 & 8.67 & 10.26 & 10.28 & 11.29 & 8.79 & 9.85 & 8.21 \\
3817 & 8.89 & 10.52 & 10.25 & 11.62 & 9.05 & 10.06 & 8.6 \\
4060 & 9.09 & 10.53 & 10.44 & 9.88 & 9.27 & 10.26 & 8.93 \\
\hline
\end{tabular}

From the record of measured hydrometric stage level and modeled water level data, 6 cases of adjusting of roughness value of minor riverbed were selected for analysis. Roughness coefficient was selected for a wide range of discharge from $180 \mathrm{~m}^{3} / \mathrm{s}$ to $4060 \mathrm{~m}^{3} / \mathrm{s}$ [15].

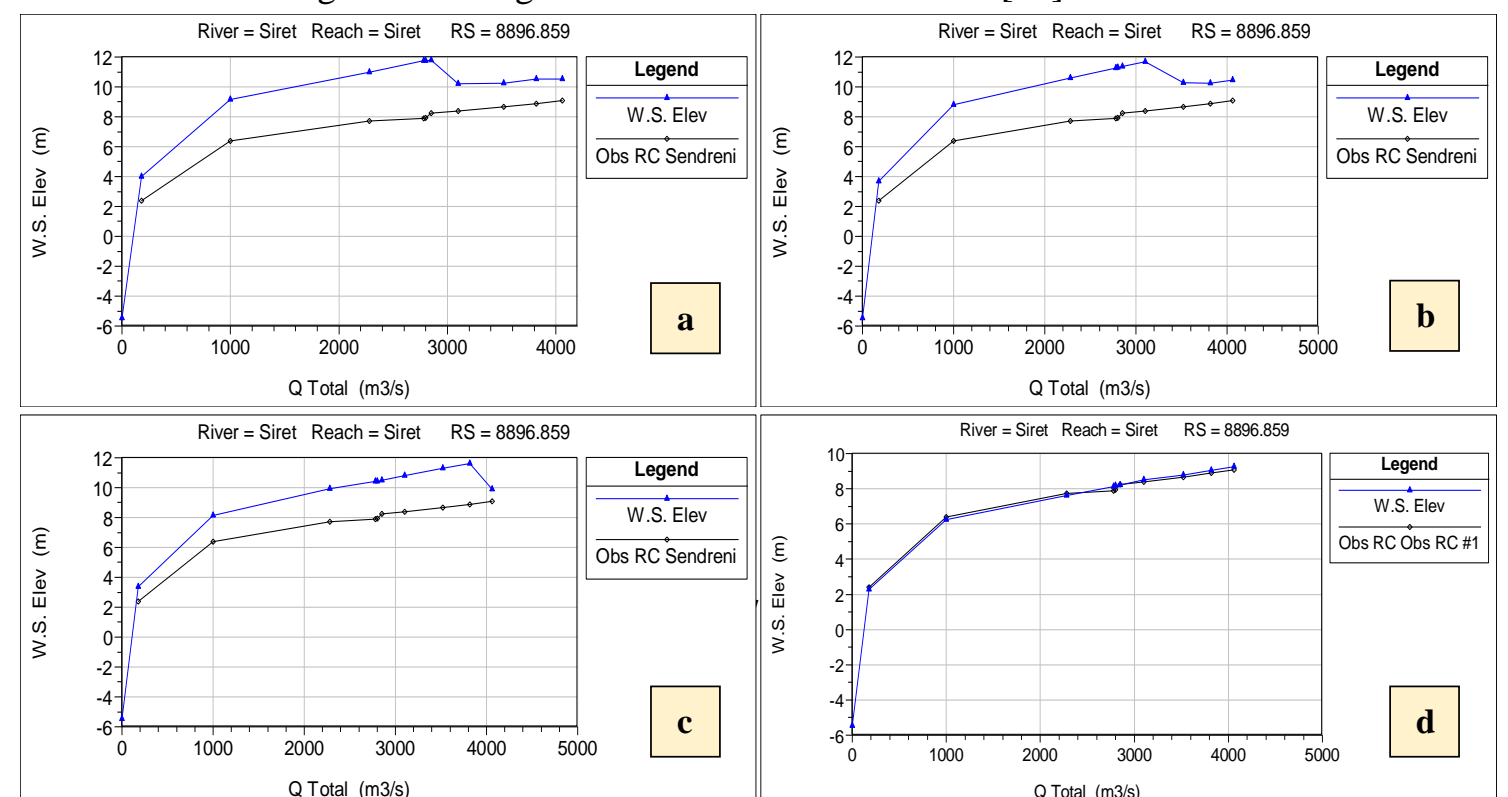


Fig. 10. Model calibration according to roughness's: a) $n=0.07$; b) $n=0.06$; c) $n=0.05$;

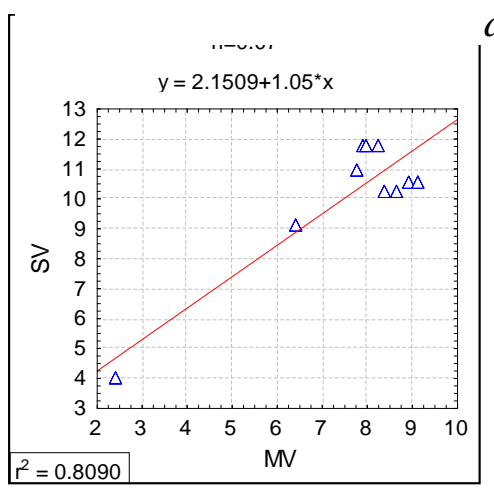
d) $n=0.04$; e) $n=0.03$; f) $n=0.02$
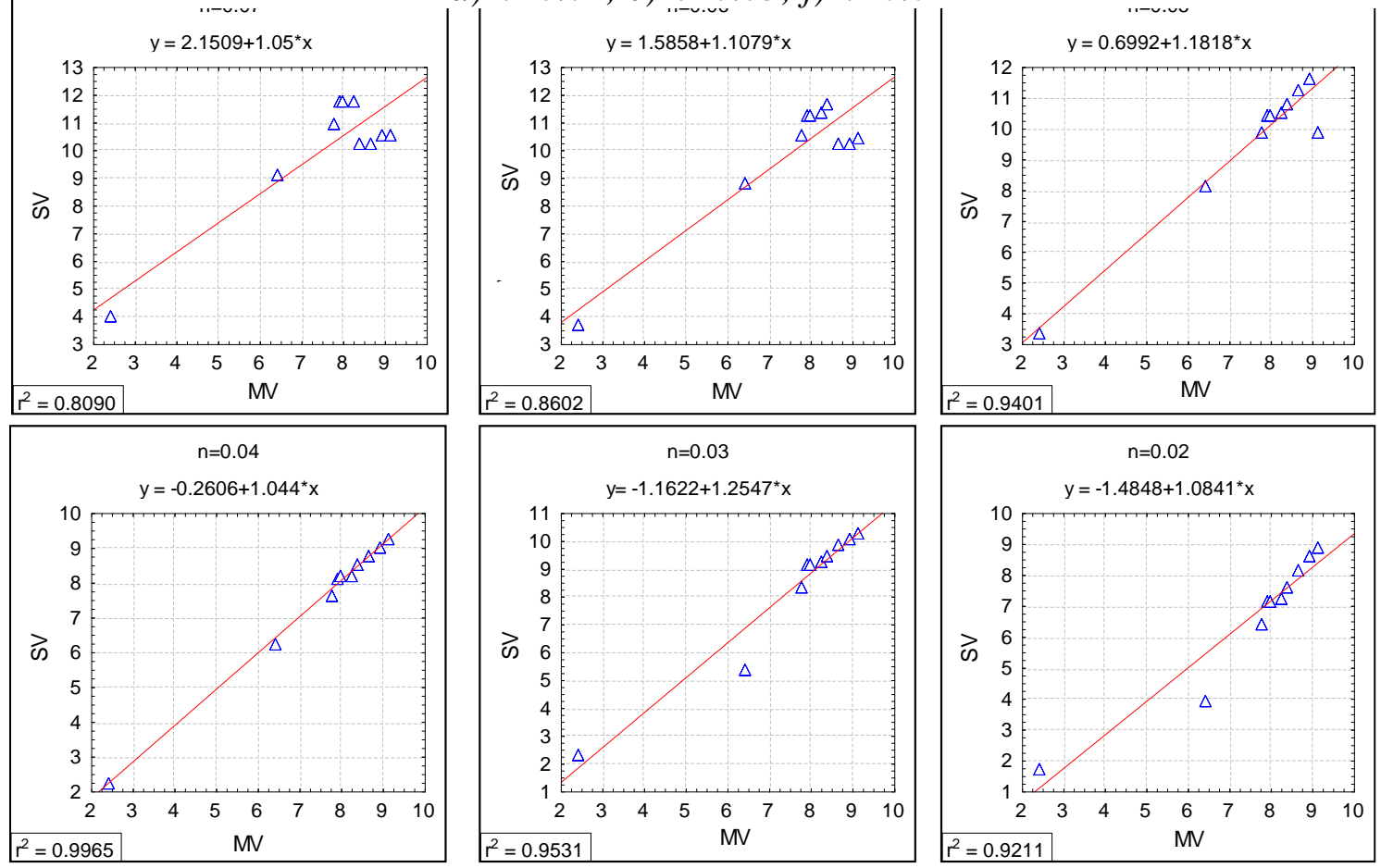

Fig. 11. The correlation between simulated and observed flow rates for Sendreni station

Following the generation of several models by varying the roughness coefficient between 0.02 and 0.07 , a value of 0.04 was chosen and the model was considered calibrated. Using this value the 
differences between the measured and the modeled water surface elevation are maximum $\pm 25 \mathrm{~cm}$. This is confirmed by the graphical representation in Figure $10-\mathrm{d}$ where the modeling limniteric key is the closest to the limnimetric key measured in the cross-sectional profile of the hydrometric station Şendreni. The values obtained from the modeling (SV, Fig. 11) were also analyzed from the point of view of their correlation with measured values (MV), thus obtaining a factor of determination $\mathrm{R}^{2}=0.9965$ for modeling with the coefficient of roughness $\mathrm{n}=0.04$. The regression analysis of discharge and roughness coefficients shows nearly identical tendencies.

\section{CONCLUSION}

On the basis of simulation carried out for the Siret River (Galati - Sendreni - Independenta section) the following findings can be summarized:

- The most effective single Manning's roughness coefficient calibrated for the minor river bed or so-called main channel of Siret River is 0.04 .

- The performance of the calibrated model has been verified for the flood of the year 2005, demonstrated by the effectiveness of modeled versus measured rating curve, and the statistical result of $\mathrm{R} 2=0.9965$.

- For flood forecasting and flood plane mapping using HEC-RAS, Manning's roughness coefficient of 0.04 may yield the best result.

- Furthermore, the calibrated Manning's roughness coefficient works best for high flow only, which needs to be verified for mean flows and low flows in the focus area research.

Based on this research study, the next step is to evaluate the expansion and compaction coefficients near bridges and elevated structures.

\section{ACKNOWLEDGMENT}

This work was supported by the project "EXPERT", financed by the Romanian Ministry of Research and Innovation, Contract no. 14PFE/17.10.2018.

\section{References}

1. G. Schumann, P. Matgen, L. Hoffmann, R. Hostache, F. Pappenberger, and L. Pfister, "Deriving distributed roughness values from satellite radar data for flood inundation modelling," J. Hydrol., vol. 344, no. 1-2, pp. 96-111, Sep. 2007.

2. L. P. Hoang et al., "Managing flood risks in the Mekong Delta: How to address emerging challenges under climate change and socioeconomic developments," Ambio, vol. 47, no. 6, pp. 635-649, Oct. 2018.

3. "Directive 2007/60/EC of the European Parliament and of the Council on the assessment and management of flood risks - European Environment Agency." [Online]. Available: https://www.eea.europa.eu/policy-documents/directive-2007-60-ec-of. [Accessed: 09-Jul2019].

4. Thesis, "Arseni M. Modern GIS techniques for determination of the territorial risks Modern GIS techniques for determination of the territorial risks," University "Dunarea de Jos" of Galati, 2018.

5. S. Moharana and K. K. Khatua, "Prediction of roughness coefficient of a meandering open channel flow using Neuro-Fuzzy Inference System," Measurement, vol. 51, pp. 112-123, May 2014.

6. VT Chow, Open-channel hydraulics. McGraw-Hill, 1959.

7. G. J. Arcement and V. R. Schneider, "Guide for Selecting Manning's Roughness Coefficients for Natural Channels and Flood Plains." Prepared in cooperation with the U.S. Department of Transportation, Federal Highway Administration, pp. 1-44, 1989.

8. P. Prasanna Nayak, "MEANDERING EFFECT FOR EVALUATION OF ROUGHNESS COEFFICIENTS AND BOUNDARY SHEAR DISTRIBUTION IN OPEN CHANNEL FLOW Master of Technology in Civil Engineering," 2010. 
9. [9] ADMINISTRAȚIA NAȚIONALĂ "APELE ROMÂNE"-, "PPPDEI, Planul pentru Prevenirea, Protecția și Diminuarea Efectelor Inundațiilor (PPPDEI) în bazinul hidrografic Siret," Bacau, 2014.

10. Administraţia Bazinala de Apa Siret, "PMRI, PLANUL DE MANAGEMENT AL RISCULUI LA INUNDAŢII," 2016.

11. M. Arseni, A. Rosu, ... C. B.-C., and undefined 2017, "Flood hazard monitoring using GIS and remote sensing observations," CARPATHIAN J. EARTH Environ. Sci., vol. 12(2), pp. 329-334, 2017.

12. J. T. Limerinos, Determination of the Manning Coefficient From Measured Bed Roughness in Natural Channels STUDIES OF FLOW IN ALLUVIAL CHANNELS. UNITED STATES GOVERNMENT PRINTING OFFICE, WASHINGTON, 1970.

13. US Army Corps of Engineers Institute for Water Resources Hydrologic Engineering Center, HEC-RAS River Analysis System Hydraulic Reference Manual, Version 5.0. 2016.

14. G. Murariu, G. Puscasu, V. Gogoncea, A. Angelopoulos, and T. Fildisis, "Non-Linear Flood Assessment with Neural Network," in AIP Conference Proceedings, 2010, vol. 1203, no. 1, pp. 812-819.

15. J. Kim, C. Lee, W. Kim, Y. K.-W. S. and Engineering, and U. 2010, "Roughness coefficient and its uncertainty in gravel-bed river," Water Sci. Eng., vol. 3(2), pp. 217-232, 2010. 


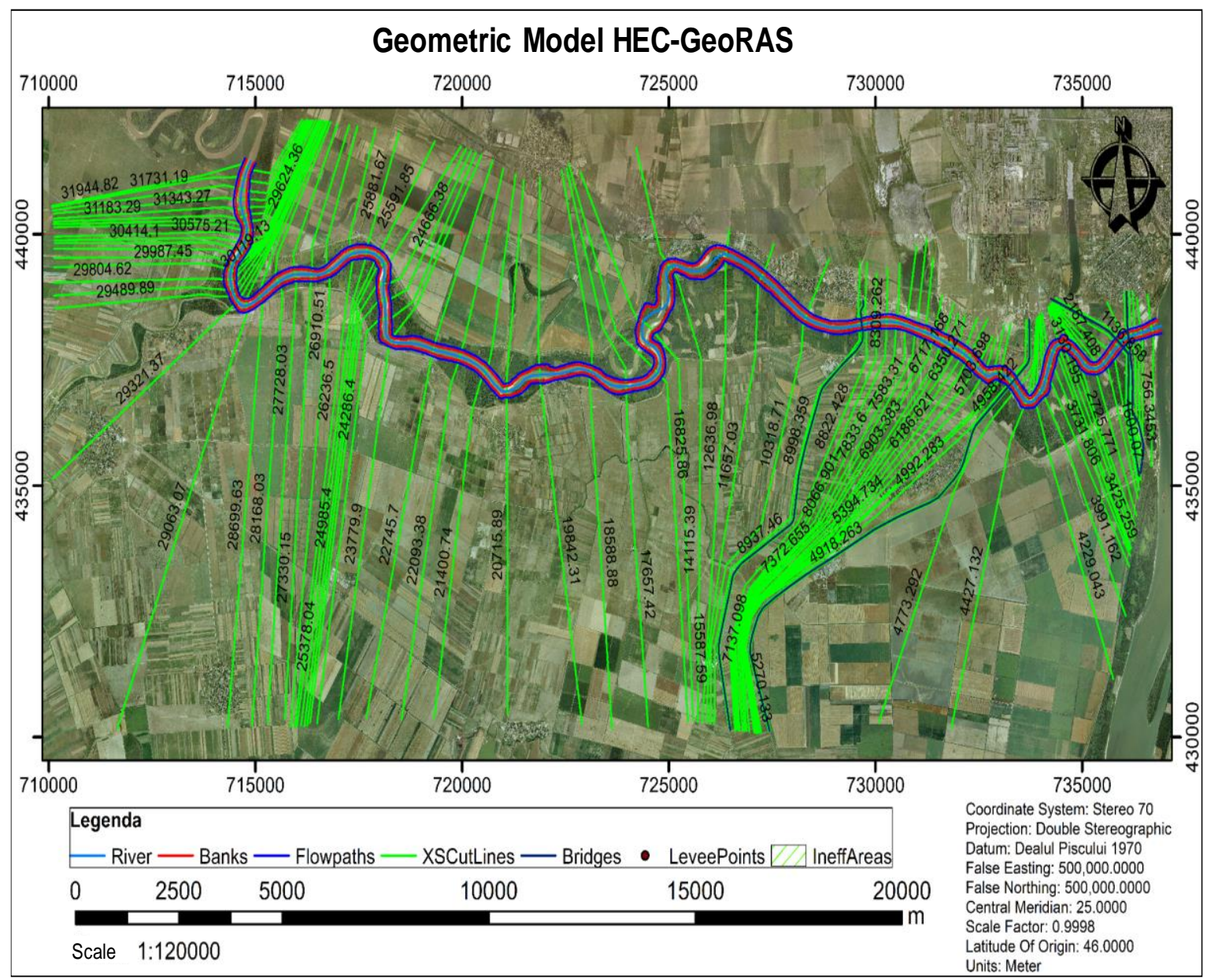

